\title{
Introduced species in the Pantanal: implications for conservation
}

\author{
Alho, CJR. ${ }^{\mathrm{a} *}$, Mamede, $S .^{\mathrm{b} *}$, Bitencourt, $\mathrm{K}^{\mathrm{c} *}$ and Benites, $M .^{\mathrm{d} *}$ \\ aPrograma de Pós-graduação em Meio Ambiente e Desenvolvimento Regional, \\ Universidade Anhanguera - Uniderp, CEP 79070-900, Campo Grande, MS, Brazil \\ 'Instituto Physis Cultura e Ambiente, Rua Dona Ana, 11b, Vila Mariana, CEP 04111-070, São Paulo, SP, Brazil \\ 'Universidade Anhanguera - Uniderp, CEP 79070-900, Campo Grande, MS, Brazil \\ ${ }^{\mathrm{d}}$ Departamento de Zootecnia, Universidade Estadual de Mato Grosso do Sul - UEMS, \\ Unidade Universitária de Aquidauana, Rod. Aquidauana/Cera, Km 12, CEP 79200-000, Aquidauana, MS, Brazil \\ *e-mail: alho@unb.br, mamede@physis.org.br, klaudiabitencourt@yahoo.com.br, maris.benites@gmail.com \\ Received October 14, 2010 - Accepted December 13, 2010 - Distributed April 30, 2011
}

\begin{abstract}
Land use and human occupation within the natural habitats of the Pantanal have facilitated introduction of invasive species of plants and animals, including domestic species. Exotic species threaten regional biodiversity because they modify ecological community structure, alter natural habitats and affect local biodiversity. An international organisation, the International Union for Conservation of Nature (IUCN), and the Brazilian government, identify invasive species as the third most important threat to biodiversity, following habitat loss and direct effect on species. In addition, exotic species carry pathogens or may function as vectors or reservoirs for diseases that affect regional biota.
\end{abstract}

Keywords: biodiversity, exotic species, invasive species, introduced species, Pantanal.

\section{Espécies introduzidas no Pantanal: implicações para conservação}

\begin{abstract}
Resumo
O uso da terra e a ocupação humana nos hábitats naturais do Pantanal têm facilitado a introdução de espécies invasivas de plantas e animais, incluindo espécies domésticas. As espécies exóticas ameaçam a biodiversidade regional porque modificam a estrutura das comunidades ecológicas, alteram hábitats e afetam a biodiversidade. A organização internacional União Internacional para a Conservação da Natureza (IUCN) e o Governo brasileiro identificam as espécies invasoras como a terceira maior ameaça para a biodiversidade, seguida da perda de hábitat e do efeito direto sobre espécies. Além disso, espécies exóticas são portadoras de patógenos ou podem funcionar como vetores ou reservatórios de doenças que afetam a biota.
\end{abstract}

Palavras-chave: biodiversidade, espécies exóticas, espécies invasivas, espécies introduzidas, Pantanal.

\section{Introduction}

Following human occupation, there have been introductions of exotic plants and animals, in a deliberate or accidental manner, with consequent alterations of the natural ecological communities within the Pantanal. An introduced species is one which occurs outside its geographical distributional range, being an alien, exotic, non-indigenous, invasive or non-native species. These species threaten biodiversity because they modify the community structure, changing the habitat and displacing native species.

The Brazilian Ministry for the Environment (Ministério do Meio Ambiente - MMA) considers introduced species the second greatest cause of species extinction, affecting biodiversity (Coradin, 2006). The Convention on Biological Diversity, signed by Brazil, in its Article 8 (h) establishes

that each country that is party to the Convention has to make efforts to control or eradicate exotic species. The MMA publication on the subject mentions 176 exotic species occurring within terrestrial environments in Brazil, including 68 invasive animal species and 108 species of flora. Additionally, 49 invasive species were identified for aquatic ecosystems of Brazilian continental waters, including one microorganism, one crustacean, six aquatic macrophytes, four mollusks and 37 species of fish. Exotic species found within the productive fields (crops, ranches and farms) were 155 species, including bacteria, fungus, insects and other arthropods.

A global population of 6 billion people and rapid means of transport increase the spread of invasive species. For example, the vector for dengue in Brazil is the mosquito Aedes 
aegypti (Linnaeus, 1762), which came from Africa, probably from the Ethiopian region, brought with slave-trafficking ships in the $16^{\text {th }}$ to $19^{\text {th }}$ centuries. Another introduced species is Aedes albopictus (Skuse, 1895), which came to Brazil in 1986 and can be the vector for yellow fever (Segura et al., 2003; Walker 2007).

The International Union for Conservation of Nature (IUCN) created the Invasive Species Specialist Group (ISSG) as a global network of scientific and policy experts to deal with introduced species. They indicate that invasive species are the third most severe threat to wild mammals after habitat loss and utilisation such as hunting for food; invasive species are also the third most severe threat to birds; the fourth cause of death among reptiles (after pollution persecution and natural disasters); and the fifth most severe threat to Amphibians (following habitat loss, pollution, diseases and fires). The IUCN maintains a database named Global Invasive Database (http://www.issg.org/database/ welcome/).

The introduction of species may be intentional or involuntary, but it is always related to human action and always results in environmental disruption (Fine, 2002). The negative effects include predation, competition, consequences of wild fire (since introduced species may recover better after a fire), and many other processes which lead to displacement of native species and alteration of natural ecological communities (Alho and Gonçalves, 2005; Alho, 2005, 2008; McGeoch et al., 2010).

The aim of this review article is to evaluate the present role of invasive exotic species within the Pantanal habitats, based on existing published knowledge, to discuss their possible effects on ecological communities and to consider the consequences of this threat on conservation objectives.

\section{Results and Discussion}

The Pantanal and its surrounding upland plateau have experienced the introduction of alien species such as the African grass Brachiaria (Griseb) spp., the feral hog Sus scrofa (Linnaeus, 1758), locally known as "porco monteiro", and recently the golden mussel Limnoperna fortunei (Dunker, 1857), locally known as "mexilhão-dourado", accidentally brought from China. The Amazonian fish "tucunaré" Cichla cf. ocellaris Bloch $\&$ Schneider 1801, a voracious predator introduced in the Pantanal, has already impacted the regional fish community. Herbivores like cattle and water buffalo can wreak great damage, since they require introduced pastures and exert pressure on native plant species.

The domestic animals introduced, with effects on natural systems, include cattle, horses, dogs, cats, chickens and many others, all from direct human action. Alien species in the Pantanal have caused alterations in the life history of native plants as well as of wild animals.

\subsection{Introduced plants}

Natural pastures of the Pantanal are mainly formed by species such as Axonopus purpusii (Mez) Chase,
Mesosetum loliiforme (Hochst. ex Steud.) and Panicum laxum Sw., covering the open fields and sandy soils of the floodplain. Other plant species forming homogeneous fields are present, such as the legume Desmodium barbatum (L.) Benth and the fura-bucho belonging to the genus Paspalum (Santos et al., 2006). Since these natural pasture fields remain submerged during the wet season, cattle ranchers are introducing exotic grassland species on the higher grounds of the Pantanal. Cultivated pastures have been expanding rapidly in the floodplain to compete with the ranchers located in the upper Cerrado plateaus surrounding the Pantanal. Two exotic species dominate the pastures: Brachiaria decumbens Stapf and Brachiaria humidicola (Rendle)Schweick. These two exotic species aggressively cover the ground and have been widely used to convert natural vegetation into cultivated pastures.

Grasses are among the invasive species with a high capacity to colonise woodland, such as denser areas of Cerrado that is being converted into open fields. In the case of $B$. decumbens, its capacity to exclude native species has been pointed out (Matos and Pivello, 2009; Oliveira, 2004). On the plateaus surrounding the Pantanal, grass species such as B. decubens and capim-gordura Melinis minutiflora Beauv. are great challenges for control in protected areas. This is also the case of Emas National Park (Parque Nacional de Emas) in the state of Goiás, east of the Pantanal. It has been shown that $B$. decumbens is the species that most benefits from wild fire, common in the region during the dry season.

There are some local plant species of the Pantanal which take advantage of disturbed areas and grow aggressively, dominating and modifying natural habitats. Species locally known as assa-peixe (Vernonia scraba Pers. and Vernonia ferruginea Less.), can colonise areas along open routes or roads. Other species which benefit from altered habitats, proliferating abnormally, are Bromelia balansae Mez. and Byrsonima intermedia A.Juss, B. orgignyana A. Juss and Licania parvifolia Huber. The bush locally known as pombeiros, belonging to the genus Combretum, can form homogeneous plots known as pombeiral after certain types of disturbance and abnormal flooding. The same trend is observed with the proliferation of the cambará (Vochysia divergens Pohl.), forming homogeneous cambarazais; and the dominance of lixeira (Curatella americana L.) forming lixeirais (Santos et al., 2006).

\subsection{Livestock}

Cattle-ranching is an important economic activity within the Pantanal. The introduction of water buffalo (Bubalus bubalis Linnaeus, 1758) is relatively recent. It is estimated that there are more than 5000 head of buffalo in the region (Mourão et al., 2002).

In addition to the conversion of natural vegetation into introduced cultivated pastures, the intensely herbivorous diet of cattle alters vegetation cover, modifying community structure. The evidence of the effects of large domestic herbivores, such as cattle and water buffalo, grazing on vegetation may be seen in recently protected areas where 
cattle used to be established: the open areas immediately recover in structure and function. Herbaceous phytomass is consumed under different grazing strategies by cattle and water buffalo, which are distinguished by their effects on herbaceous productivity. There are direct effects on plant productivity and survival; besides constant loss of biomass to herbivores, grazing usually results in the introduction of exotic species. Large domestic herbivores affect vegetation, both directly by consuming a large portion of its biomass and also indirectly by being selective in preferred items, compacting the soil, foraging on woody vegetation (browsing) and dispersing seed-propagating species, such as the acuri palm tree Attalea phalerata Mart. ex Spreng.

\subsection{Feral pig}

The feral pig, known in the Pantanal as porco-monteiro, escaped from domestic herds and became wild. These animals form groups, then damaging crops, digging up large areas of native vegetation, particularly near the depressions with temporary or permanent water known as baías, and may transmit disease to wildlife. It has been estimated that there are nearly 10,000 groups of porco-monteiro in the Pantanal (Mourão et al., 2002). It is more abundant in the sub-region of Aquidauana and within the regions with less flooding, such as Nhecolândia and Paiaguás. A study carried out in the Pantanal of Rio Negro, between April 2003 and March 2004, showed that the porco-monteiro was the second most abundant mammal in the survey, second only to capybara Hydrochoerus hydrochaeris Linnaeus, 1766 (Mamede, 2004). Seasonally flooded habitats are preferred by the animals, which particularly forage in sites near temporary baías.

The porco-monteiro has rapidly adapted to the environmental conditions of the Pantanal, with morpho-physiological and behavioural characteristics that resemble its original wild ancestors more than the domestic pig. They are omnivorous and can occasionally prey upon young animals. They also take eggs and all kinds of soil invertebrates and vertebrate species they are able to capture. Local residents hunt juveniles for food. Some of the young males are captured, castrated and released to be caught again, when older, for food.

Feral pigs probably occupy the same habitat requirements that local white-lipped peccary or queixada (Tayassu peccary Link, 1795) and collared peccary cateto (Pecari tajaco Linnaeus, 1758) do, particularly in terms of feeding strategies (Sicuro and Oliveira, 2002). Niche partitioning among sympatric populations of white-lipped peccary, collared peccary, and feral hog was evaluated using an ecomorphological approach: morphofunctional data suggest that feral hogs have a powerful bite and are able to feed on seeds of different degrees of resistance (Sicuro and Oliveira, 2002). This study indicates that with an optimised lever system of head elevation, feral pigs are more efficient than peccaries at rooting. In addition, feral hogs explore a wide range of habitats, which supports the view that the invasive species acts as a potential competitor of native peccaries. However, overlaps in food resources and habitat use between feral pigs and peccaries in the Pantanal were found to be lower than expected (Desbiez et al. 2009). In fact, this study shows that niche overlap was highest between the native species. Differences in morphology and behaviour indicate possible mechanisms of niche partitioning between the species.

\subsection{African bees}

The African bee Apis mellifera scutellata (Lepeletier 1836) was introduced into Brazil in 1956 and has spread throughout the country and others in the region. The so-called 'africanized bee' or abelha africanizada is a hybrid of the European bee Appis mellifera mellifera Linnaeus, 1758. It has adapted very well to the environmental conditions of the biome and exhibits aggressive behaviour, attacking humans and animals, such as horses, in the Pantanal.

\subsection{Introduced fishes}

The tucunaré is believed to have been introduced in the region in the 80 's. It is thought that the introduction occurred in 1982, when a water reservoir for raising tucunaré broke, releasing the fishes into the Itiquira and Piquiri rivers, on the border of the states of Mato Grosso and Mato Grosso do Sul (Ferraz de Lima, 1993). Surveys carried out indicate that tucunarés were confined to the Piquiri river basin between 1992 and 1994 (Nascimento et al., 2001). However, over the following years, the fish has been reported occurring in other river basins of the Pantanal, including in several localities along the left bank of the Paraguay river, São Lourenço River and Paraguay-Mirim River, (Marques and Resende, 2005). The tucunaré does not migrate for reproduction and prefers clear and non-turbulent water.

This large fish is a voracious Amazonian carnivore preying upon native species, competing for food and space with local species, disrupting ecological fish communities in a cascading scale in the trophic food chain (Harris et al., 2005). However, there are no regional studies on the real role of tucunaré in the Pantanal aquatic habitats.

Another fish species recorded in the Pantanal is the Amazonian tambaqui (Colossoma macropomum Cuvier, 1816) whose biology resembles the natural history of the local pacu (Piaractus mesopotamicus Holmberg, 1887), both feed largely on fallen fruits and seeds.

\subsection{Introduced mollusk}

The bivalve mollusk Limnoperna fortunei (Dunker, 1857), known as mexilhão-dourado, was introduced into the Paraná-Paraguay rivers and has reached the Pantanal. It arrived in Argentina's River Plate in 1991, brought by ships from China (Darrigan and Pastorino, 1995, 2003; Oliveira et al., 2000). Ships arriving from Asia had discharged ballast water containing the mussels or their larvae into the Plate. From this river, the molluscs reached the Paraná-Paraguay rivers, giving them access to the vast Pantanal wetland.

It has been reported to occur in the Paraguay River since 1998, up to the region of Bela Vista do Norte, near the tributary of the Cuiabá River, in several lakes or baías adjacent to the Paraguay River; and later on, in 2003, it 
was also reported in the Miranda river, near the region of Passo do Lontra (Oliveira, 2003).

It also occurs at the bottom of a lake (Baía do Tuiuiú $-18^{\circ} 49^{\prime} 18^{\prime}$ S and $57^{\circ} 39^{\prime} 13^{\prime}$ W), near Corumbá city. In 1999 it was registered in the Paraguay River (17 38' 04" S and 57 41' 45" W), near Forte Coimbra, encrusted on rocks. However, a study carried out by Oliveira (2003) points out that the densities of mexilhão-dourado in the Paraguay river (10,000 individuals/ $\left.\mathrm{m}^{2}\right)$ are lower than the densities found in aquatic habitats in southern Brazil (100,000 individuals/ $\mathrm{m}^{2}$ ).

Another introduced mollusk is the African snail Achatina fulica Bowdich, 1822, which arrived in Brazil around 1980, brought to substitute the escargot Helix aspersa Müller, 1774 as a delicacy (Carvalho Jr. and Nunes, 2009). Achatina fulica is partially an arboreal and herbivore generalist species and was introduced into the Pantanal as bait brought by fishermen. This African mollusk is currently found throughout the Pantanal (Carvalho Jr. and Nunes, 2009; Instituto Horus, 2009; Teles et al., 1997).

The North-American frog Rana catesbeiana Shaw, 1802 = Lithobates catesbeianus (Shaw, 1802) was introduced into Brazil to be raised as a food source; it accidentally escaped and is now found in several different regions. There is no official record of this species in the Pantanal, but some people claim to have heard its call.

\subsection{Dogs, cats, rats, mice and others}

Domestic or pest mammal species introduced by man into the Pantanal, including the domestic dog Canis familiaris Linnaeus, 1758, cat Felis catus Linnaeus, 1775, mouse Mus musculus (Linneaus, 1758) and black rat Rattus rattus (Linnaeus, 1758), are potential predators of wildlife and infest ecological ecosystems, spreading diseases and causing habitat degradation. Cats are known to prey on birds' nests and on lizards, amphibians and other small animals. Dogs are trained to hunt wildlife. In some protected areas feral dogs may impact biodiversity. The effect of these alien invasive species may be viewed as the simple and direct effect of one given introduced species on any natural ecosystem. However, in a more complex analysis, considering a greater number of variables that can be identified and derived from invasive species, domestic mammals and others can be examined simultaneously interacting among themselves as well as with the native species. The result is generally the impoverishment of local biodiversity. These species may also carry diseases that affect wildlife and man: dogs, for example, harbour the pathogen of leishmaniasis.

\subsection{Concluding remarks}

From the introduced species reviewed here, the adverse effect of invasive species on biodiversity and natural habitats of the Pantanal is evident. Some alterations in community structure and function have been rapid and highly noticeable, while others are slow but ongoing; both trends, however, impact local biota.
By interacting with many species in a variety of ways, introduced species affect, in an array of changes, the ecological communities. Interactions among the species are essential in the function of communities holding the interacting species together and determine their specific roles. The most prominent processes are competition, predation, parasitism, herbivory, and mutualism.

We need specific studies to characterise negative impacts qualitatively as well as quantitatively. With the present knowledge, all we can observe are the most immediate and obvious effects on local biodiversity and natural habitats. Introduced species in the Pantanal obviously rely on predation, browsing, competition for food, nest sites, in addition to potential transmission of diseases. One of these effects or the sum of them may alter community structure and function and habitat quality; in this case, for example, in terms of habitat loss by native species, due to environmental changes.

The negative impact of an exotic species on a population of native species of plants and animals is to reduce the population density of the vulnerable local species. In this case, the negative impact may cause a direct effect on the local species (competition for food or nesting site, for example) or adverse effects on habitat quality.

When an ecological community of interacting animals and plants are disrupted, invasive species can take advantage of the changed conditions to establish themselves. In some habitats of the Pantanal introduced species become part of the landscape, while others thrive at the expense of native species. In many cases the invasive species exerts additional stresses on the local and native species, with disruption to community structure and function. Since the invasive species does not have the natural predators from its original land to keep its numbers in check, it is able to spread throughout new habitats in the Pantanal. As soon as the invasive species of plant or animal becomes established, these invaders become hard to control. As we have seen in the cases of the feral pig porco-monteiro and the introduced Amazonian fish tucunaré they prey on or compete with native species. In terms of fauna, introduced African grass species drastically modify the species composition of open habitats of the Pantanal.

There is no specific control programme in the Pantanal to restore and prevent new invasions and keep established invasive species in check. Inside a broad conservation programme, there is the need to restore, protect and preserve natural habitats, including research into invasive species in ecological communities and ecosystems, to keep these established invaders under control.

Acknowledgements - We thank the organisers of this Volume and participants, especially Dr. José Tundisi (Executive Editorial Board of Brazilian Journal of Biology), Dr. Takako Matsumura-Tunidsi (Editor in Chief of the Journal) and Prof. Elizabeth Brunini Sbardelini (University Anhanguera/Uniderp). We are grateful to Celina Alho for assistance in preparing the manuscript, providing helpful comments and organising its structure. Susan Casement reviewed the language. 


\section{References}

ALHO, CJR., 2005. The Pantanal. In FRASER, LH. and KEDDY, PA., Org. The World's Largest Wetlands - Ecology and Conservation. New York, USA: Cambridge University Press. p. 203-271.

-, 2008. Biodiversity of the Pantanal: response to seasonal flooding regime and to environmental degradation. Revista Brasileira de Biologia = Brazilian Journal of Biology, vol. 68, no. 4, p. 957-966. Suppl.

ALHO, CJR. and GONÇALVES, HC., 2005. Biodiversidade do Pantanal: ecologia e conservação. Ed. UNIDERP. 142 p.

CARVALHO Jr., VCB. and NUNES JRS., 2009. Occurrence and distribution of the african snail "Achatina fulica" Bowdich, 1822, at the county of casa grande, state of mato grosso. Engenharia Ambiental, vol. 6, no. 2, p. 620.

CORADIN, L., Org., 2006. Espécies exóticas invasoras: situação brasileira. Brasília: Ministério do Meio Ambiente, Secretaria de Biodiversidade e Florestas. 24 p.

DARRIGAN, G. and PASTORINO, G., 1995. The recent introduction of Asiatic Bivalve, Limnoperna fortunei (Mytilidae) into South America. The Veliger, vol. 38, no. 2, p. 183-187.

DARRIGAN, G. and PASTORINO, H., 2003. The golden mussel Limnoperna fortunei (Dunker, 1857) (Bivalvia: Mytilidae), in the Neotropical region: a 10-year story of invasion. Tentacle, no. 11, p. $8-9$.

DESBIEZ, ALJ., SANTOS, SA., KEUROGHLIAN, A. and BODMER, RE., 2009. Niche partitioning among white-lipped peccaries (Tayassu pecari), Collared Peccaries (Pecari tajacu), and Feral Pigs (Sus Scrofa). Journal of Mammalogy, vol. 90, no. 1, p. 119-128.

FERRAZ DE LIMA, JA., 1993. Recursos Pesqueiros em ambientes inundáveis (rio Cuiabá: Pantanal de Mato Grosso). In: Anais do Encontro Brasileiro de Ictiologia, 1993. Sociedade Brasileira de Ictiologia, Universidade de São Paulo.

FINE, PVA., 2002. The invasibility of tropical forests by exotic plants. Journal of Tropical Ecology, vol. 18, no. 5, p. 687-705.

HARRIS, MB., TOMAS, W., MOURÃO, G., SILVA, CJ., GUIMARÂES, E., SONODA, F. and FACHIM, E., 2005. Safeguarding the Pantanal Wetlands: threats and conservation iniciatives. Conservation Biology, vol. 19, no. 3, p. 714-720.

Instituto Horus, 2009. Rota de dispersão do caramujo Achatina fulica introduzido no Brasil. Available from: <http://www. institutohorus.org.br/download/fichas/Achatina_fulica.htm. Access in: 15 nov. 2009.

MAMEDE, SB., 2004. Diversidade, abundância, sazonalidade e conservação da mastofauna terrestre do Pantanal do Negro e do Miranda-Aquidauana. Universidade para o Desenvolvimento do Estado e da Região do Pantanal - UNIDERP. Dissertação de mestrado em meio ambiente e desenvolvimento regional.
MARQUES, DKS. and RESENDE, EK., 2005. Distribuição do Tucunaré Cichla cf. monoculus (Osteichthyes, Ciclidae) no Pantanal. Corumbá: Embrapa Pantanal. Boletim de Pesquisa, no. 60.

MATOS, DMS. and PIVELLO, VR., 2009. O impacto das plantas invasoras nos recursos naturais de ambientes terrestres: alguns casos brasileiros. Ciência e Cultura (SBPC), vol. 61, p. 27-30.

McGEOCH, MA., BUTCHART, SHM., SPEAR, D., MARAIS, E., KLEYNHANS, EJ., SYMES, A., CHANSON, J. and HOFFMANN, M., 2010. Global indicators of biological invasion: species numbers, biodiversity impact and policy responses. Diversity and Distributions, vol. 16, no. 95-108.

MOURÃO, G., COUTINHO, ME., MAURO, R., TOMÁS W. and MAGNUSSON, W., 2002. Levantamentos aéreos de espécies introduzidas no Pantanal: porcos ferais (porco monteiro), gado bovino e búfalos. Embrapa Pantanal. p.1-22. Boletim de Pesquisa e Desenvolvimento, no. 28.

NASCIMENTO, FL., CATELLA, AC., MORAES, AE., 2001. Distribuição espacial do tucunaré, Cichla sp. (Pisces, Cichlidae), peixe amazônico introduzido no Pantanal, Brasil. Corumbá: Embrapa Pantanal, 17 p. Boletim de Pesquisa, no. 24.

OLIVEIRA, MD., 2003. Ocorrência e impactos do Mexilhão dourado Limnoperna fortunei (Dunker, 1857) no Pantanal Mato-Grossense. Corumbá, MS: EMBRAPA. p. 6. Circular Técnica, no. 38.

-, 2004. Introdução de espécies: uma das maiores causas de perda de biodiversidade. Corumbá, MS: Embrapa Pantanal. p. 1-3.

OLIVEIRA, MD., TAKEDA, AM., BARBOSA, DS. and CALHEIROS, DF., 2000. Ocorrência da especie exótica Limnoperna fortunei (Bivalvia, Mytilidae) no Rio Paraguai, Pantanal, Brasil. In: Resumos do III Simpósio Sobre Recursos Naturais e Socio-Economicos do Pantanal. Os desafios do novo milênio. Corumba: Embrapa Pantanal. p. 264-265.

SANTOS, SA., CUNHA, CN., TOMÁS, W., ABREU, UGP. and ARIEIRA, J., 2006. Plantas invasoras no Pantanal: como entender o problema e soluções de manejo por meio de diagnóstico participativo. EMBRAPA-Pantanal. 45 p. Boletim de Pesquisa e Desenvolvimento, no. 66.

SEGURA, MNO., MONTEIRO, HAO., LOPES, ES., SILVA, OV., CASTRO, FC. and VASCONCELOS, PFC., 2003. Encontro de Aedes albopictus no Estado do Pará, Brasil. Revista de Saúde Pública, vol. 37, no. 3, p. 388-389.

SICURO, FL. and OLIVEIRA, LFB., 2002. Coexistence of peccaries and feral hogs in Brazilian Pantanal wetland: an ecomorphological view. Journal of Mammalogy, vol. 83, no. 1, p. 207-217.

TELES, HMS., VAZ, JF., FONTES, LR. and DOMINGOS, MF., 1997. Occurrence of Achatina fulica Bowdich, 1822 (Mollusca, Gastropoda) in Brazil: intermediate snail host of angiostrongyliasis. Revista Saúde Pública, 1997, vol. 31, no. 3, p. 310-12.

WALKER, K., 2007. Asian Tiger Mosquito (Aedes albopictus) pest and diseases image library. Available from: http://www.padil.gov.au. Access in: 22 dez. 2007. 